\title{
molecules
}

ISSN 1420-3049

http://www.mdpi.org

\section{Convenient Synthesis of Two Mango Allergens}

\author{
Shyam V. Trivedi, Ayyulur S. Subbaraman, Subrata Chattopadhyay and Vasant R. \\ Mamdapur* \\ Bio-Organic Division, Bhabha Atomic Research Centre, Mumbai - 400 085, India 57007 \\ Tel.: (022)-550-5050, Fax: (022) 550-5151, E-mail: schatt@apsara.barc.in \\ * Author to whom correspondence should be addressed.
}

Received: 10 September 1998 / Accepted: 16 July 1999 / Published: 30 August 1999

\begin{abstract}
The mango allergens, 5[2'(Z)-heptadecenyl]resorcinol (10) and 5[12'(Z)heptadecenyl]resorcinol (20) have been synthesized by simple routes using easily accessible starting materials.
\end{abstract}

Keywords: Mango allergens, synthesis, phenolics.

\section{Introduction}

It is by now established [1] that several long chain phenolic compounds act as natural allergens imparting resistant properties to plants. Amongst the various sources of the allergens, the cashew nut shell as well as the Japanese and Chinese lacs are well known for producing the phenolic compounds like cardols [2] and urushiols [3]. Sometimes back, we have isolated [4] a non-volatile allergen, 5[2'(Z)-heptadecenyl]resorcinol (10) from the mango latex. Subsequently, another isomeric resorcinol viz. 5[12'(Z)-heptadecenyl]resorcinol (20) was isolated by Cojocaru et al. [5] from raw mango fruit peel. They have demonstrated that these phenolic compounds also act as preservatives in the necrotic organs of the plants against microbial infection. Considering that occupational allergenic contact dermatitis is a growing problem in the green house industry, the study of mango allergen seems interesting. With this aim, we have developed a novel synthesis of the above compounds in sufficient quantities to study their allergen and other biological activities. The synthesis (Scheme 1) is brief and conveniently produces the target compounds from easily accessible starting materials.

(C) 1999 by the authors. Reproduction of this article, by any means, is permitted for noncommercial purposes. 

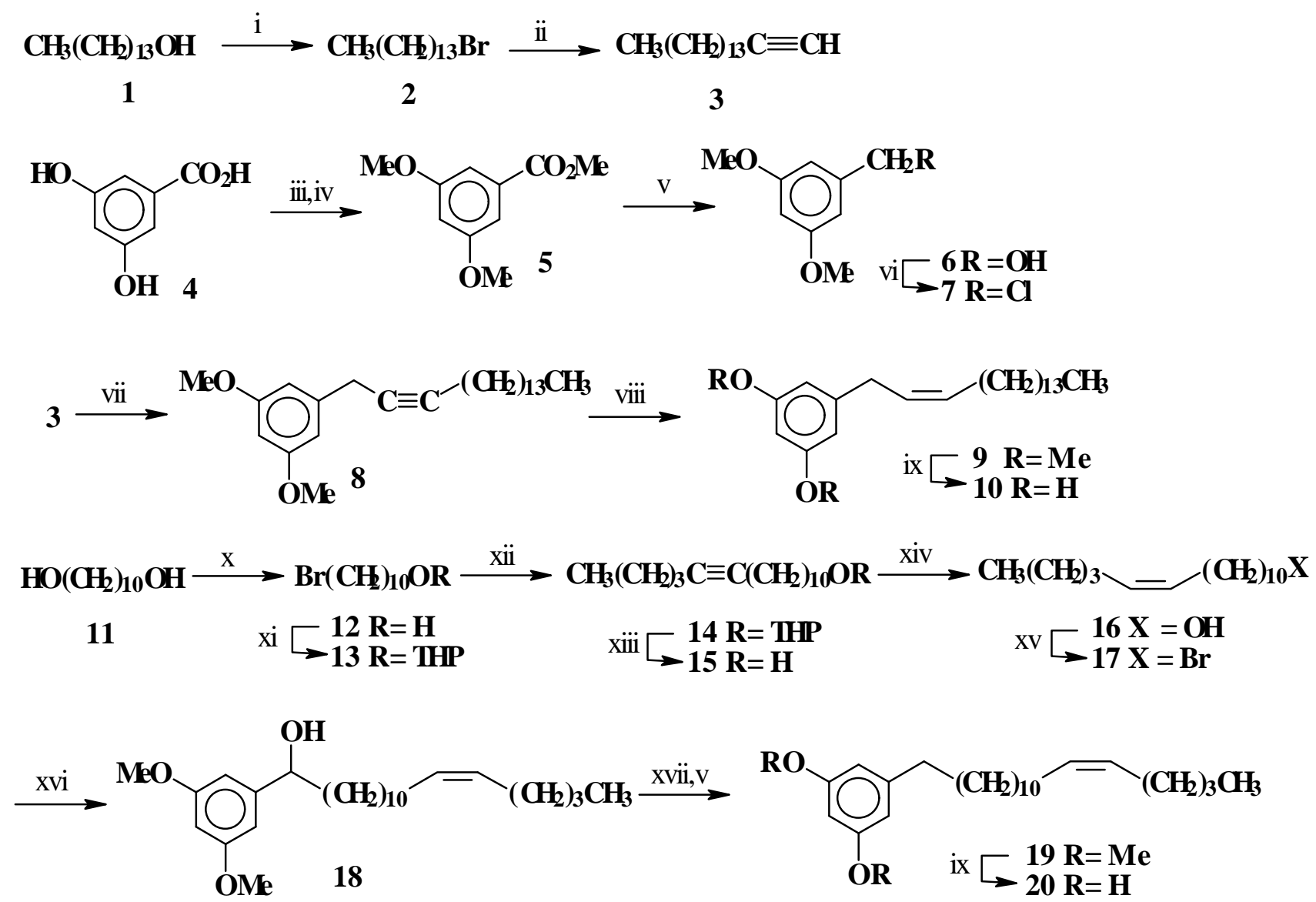<smiles>[R20]c1cc([R20])cc(CCCC=CCCC)c1</smiles>

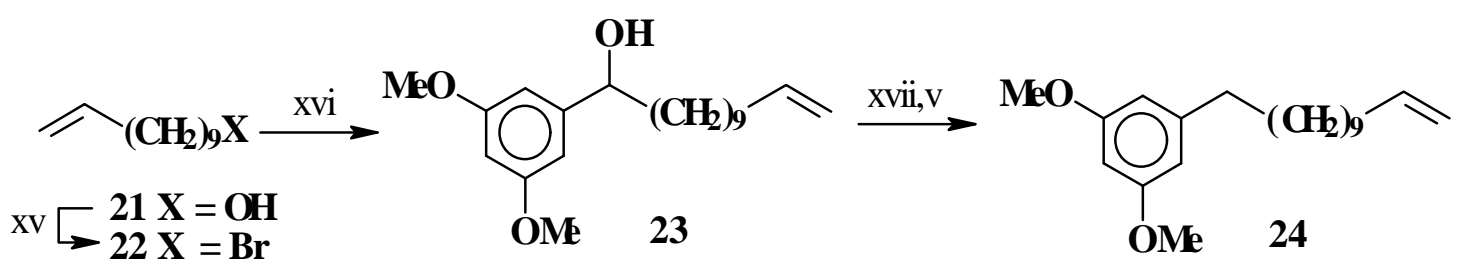<smiles>[R20]Oc1cc(CCCCCCCC)cc(O[R20])c1</smiles>

i) $\mathrm{HBr} / \mathrm{H}_{2} \mathrm{SO}_{4} / \Delta$, ii) Sod. acetylide/ $\mathrm{NH}_{3}$, iii) $\mathrm{MeOH} / \mathrm{BF}_{3}$. Et $t_{2} \mathrm{O}$, iv) $\mathrm{Me}_{2} \mathrm{SO}_{4} / \mathrm{K}_{2} \mathrm{CO}_{3} /$ acetone/ $\Delta$,

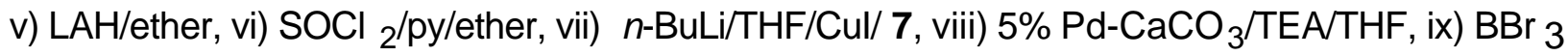
x) $\mathrm{HBr} /$ heptane/ $\Delta$, xi) DHP/PPTS/ $\mathrm{CH}_{2} \mathrm{Cl}_{2}$, xii) $\mathrm{NaNH}_{2} / 1$-hexyne/THF/-78 ${ }^{\circ} \mathrm{C}$, xiii) MeOH/PTS/ $\Delta$, xiv) $\mathrm{H}_{2} / \mathrm{P}-2 \mathrm{Ni} / \mathrm{EtOH} / \mathrm{EDA}$, xv) $\mathrm{Ph}{ }_{3} \mathrm{P} . \mathrm{Br}_{2} / \mathrm{py} / \mathrm{CH}_{2} \mathrm{Cl}_{2}$, xvi) $\mathrm{Mg} / \mathrm{THF} / 3,5$-dimethoxtbenzaldehyde, xvii) $\mathrm{MsCl} / \mathrm{TEA} / \mathrm{CH}_{2} \mathrm{Cl}_{2}$, xviii) $\mathrm{NaBH}_{4} / \mathrm{TiCl}_{4} / \mathrm{DME}$, xix) $\mathrm{PCC} / \mathrm{CH}_{2} \mathrm{Cl}_{2}$, xx) Dimsyl ion/THF/ $\mathrm{CH}_{3}\left(\mathrm{CH}_{2}\right)_{4} \mathrm{PPh}_{3} \mathrm{Br}$.

Scheme 1. 


\section{Results and Discussion}

Synthesis of 5[2'(Z)-heptadecenyl]resorcinol (10)

Commercially available 1-tetradecanol (1) was converted to the bromide $\mathbf{2}$ via a standard route and reacted with monosodium acetylide [6] to furnish the alkyne 3. For the required aromatic moiety, 3,5dihydroxybenzoic acid (4) was converted to the ester 5 by esterification followed by methylation. Its LAH reduction to the alcohol 6 followed by chlorination gave compound 7. Alkylation [7] of the alkyne 3 with the chloride 7 was accomplished using $n$-BuLi as the base in the presence of $\mathrm{CuI}$ to furnish 8. Its cis-selective partial hydrogenation afforded the dimethyl ether $\mathbf{9}$ which was demethylated with $\mathrm{BBr}_{3}$ to furnish the target allergen $\mathbf{1 0}$.

\section{Synthesis of 5[12'(Z)-heptadecenyl]resorcinol (20)}

This was synthesized by two methods. In the first route, 1,10-decanediol (11) was monobrominated [8] to the bromohydrin $\mathbf{1 2}$ which on pyranylation gave compound 13. Alkylation of 1-hexyne with $\mathbf{1 3}$ followed by acid catalyzed depyranylation afforded the alcohol 15. Its cis-selective partial hydrogenation over P-2 Ni [9] produced the alkenol 16 which was brominated with $\mathrm{Ph}_{3} \mathrm{P} . \mathrm{Br}_{2}$ [10] to furnish 17. This was then converted to the corresponding Grignard reagent and reacted with 3,5dimethoxybenzaldehyde yielding compound 18. Its mesylation and susequent reduction with LAH gave 19.

In an alternative approach, 10-undecenol (21) was brominated to give 22. As above, the Grignard reagent prepared from 22 was reacted with 3,5-dimethoxybenzaldehyde to furnish the alcohol $\mathbf{2 3}$ which on mesylation and LAH reduction afforded the alkene 24. This on anti-Markonikov hydration with $\mathrm{NaBH}_{4}-\mathrm{TiCl}_{4}$ [11] followed by pyridinium chlorochromate (PCC) [12] oxidation gave the aldehyde 26. Its $Z$-selective Wittig olefination with $n$-pentyltriphenylphosphonium bromide in the presence of dimsyl ion as the base led to 19. As done for $\mathbf{1 0}$, demethylation of 19 with $\mathrm{BBr}_{3}$ afforded the title compound 20. The spectral and microanalytical data of both the synthetic samples were in good agreement with those reported $[4,5]$ in literature.

\section{Experimental}

\section{General}

All the boiling points are uncorrected. The IR spectra were scanned with a Perkin-Elmer spectrophotometer model 837. The PMR spectra were recorded in $\mathrm{CDCl}_{3}$ with a Varian A-60 (60 $\mathrm{MHz}$ ) instrument. The GLC analyses were carried out using Shimadzu GC-7A chromatograph using a $3 \%$ OV-17 column and a $\mathrm{N}_{2}$ flow rate $40 \mathrm{~mL} / \mathrm{min}$. Anhydrous reactions were carried out under $\mathrm{Ar}$ using freshly dried solvents. The organic extracts were dried over anhydrous $\mathrm{Na}_{2} \mathrm{SO}_{4}$. 


\section{1-Bromotetradecane (2)}

A mixture of the alcohol $1(21.4 \mathrm{~g}, 0.1 \mathrm{~mol}), 48 \% \mathrm{HBr}(50 \mathrm{~mL})$ and $\mathrm{H}_{2} \mathrm{SO}_{4}(5 \mathrm{~mL})$ was heated for $8 \mathrm{~h}$ at $130{ }^{\circ} \mathrm{C}$, brought to room temperature, diluted with water and extracted with ether. The ether layer was washed several times with half-saturated brine, dried, concentrated and distilled under reduced pressure to give pure 2. yield: $23.5 \mathrm{~g}$ (85\%); bp: $118-120{ }^{\circ} \mathrm{C} / 2 \mathrm{~mm}$; IR: 2950, 2880, 1475 , $1265 \mathrm{~cm}^{-1}$; PMR: $\delta 0.9$ (dist. t, 3H), 1.27 (br. s, 24H), 3.4 (t, $J=6 \mathrm{~Hz}, 2 \mathrm{H}$ ).

\section{1-Hexadecyne (3)}

A solution of sodium acetylide $(0.13 \mathrm{~mol})$ in $\mathrm{NH}_{3}(100 \mathrm{~mL})$ was prepared as described [13] in literature. Ammonia was slowly removed and the bromide 2 (13.85 g, $0.05 \mathrm{~mol}$ ) in DMF (30 mL) was added to it in $0.5 \mathrm{~h}$. The mixture was heated at $70{ }^{\circ} \mathrm{C}$ for $4 \mathrm{~h}$, brought to room temperature and treated with aqueous saturated $\mathrm{NH}_{4} \mathrm{Cl}$ solution. It was diluted with water, extracted with ether, the ether layer washed with water and brine and dried. Removal of solvent followed by distillation of the residue gave pure 3. yield: $7.0 \mathrm{~g}$ (65\%); bp: $103{ }^{\circ} \mathrm{C} / 1 \mathrm{~mm}$, (lit. [14] bp: $115{ }^{0} \mathrm{C} / 5 \mathrm{~mm}$ ); IR: 3320, 2860, $2120 \mathrm{~cm}^{-1}$; PMR: $\delta 0.87$ (dist. t, 3H), 1.3 (br. s, 24H), 1.9-2.18 (m, 3H).

\section{Methyl 3,5-Dimethoxybenzoate (5)}

A mixture of the acid $4(15.4 \mathrm{~g}, 0.1 \mathrm{~mol})$ and $\mathrm{BF}_{3} \cdot \mathrm{Et}_{2} \mathrm{O}(2.0 \mathrm{~mL})$ in $\mathrm{MeOH}(100 \mathrm{~mL})$ was refluxed for $12 \mathrm{~h}$. Most of the solvent was removed in vacuo, water added to the residue which was extracted with ether. The ether layer was washed aqueous $10 \% \mathrm{NaHCO}_{3}$, water and brine and dried. Removal of solvent followed by crystallization gave the ester of 4. yield: $13.5 \mathrm{~g}(80 \%)$; $\mathrm{mp}: 165{ }^{0} \mathrm{C}$; IR: 3380 , 1700, $1610 \mathrm{~cm}^{-1}$; PMR: $\delta 3.86$ (s, 3H), 6.6-7.2 (m, 3H), 12.9 (br. s, $\mathrm{D}_{2} \mathrm{O}$ exchangeable, $2 \mathrm{H}$ ).

A mixture of the above ester $(8.4 \mathrm{~g}, 0.05 \mathrm{~mol})$, dimethyl sulphate $(14.2 \mathrm{~mL}, 0.15 \mathrm{~mol})$ and anhydrous $\mathrm{K}_{2} \mathrm{CO}_{3}(27.6 \mathrm{~g} 0.2 \mathrm{~mol})$ in acetone $(100 \mathrm{~mL})$ was refluxed for $16 \mathrm{~h}$. After bringing to room temperature, the reaction mixture was filtered, concentrated and worked-up as above. Removal of solvent followed by crystallization $\left(\mathrm{MeOH}-\mathrm{H}_{2} \mathrm{O}\right)$ gave 5. yield: $8.4 \mathrm{~g}(86 \%)$; mp: $\quad 43{ }^{0} \mathrm{C}$, (lit. [15] mp: $42{ }^{\circ} \mathrm{C}$ ); UV: 252 (log e 3.76), 306 (log e 3.46) nm; IR: 3050, 1750, 1580, $1210 \mathrm{~cm}^{-1}$; PMR: $\delta 3.83$ (s, 6H), 3.93 (s, 3H), 6.62-7.12 (m, 3H); MS (m/z): $196\left(\mathrm{M}^{+}\right)$, 165, 138, 122, 104, 92, 79.

\section{3,5-Dimethoxybenzyl alcohol (6)}

To a stirred suspension of LAH $(3.8 \mathrm{~g}, 0.1 \mathrm{~mol})$ in ether $(50 \mathrm{~mL})$ was added a solution of $\mathbf{5}(7.84 \mathrm{~g}$, $0.04 \mathrm{~mol})$ in ether $(30 \mathrm{~mL})$. The reaction mixture was refluxed for $3 \mathrm{~h}$, brought to room temperature and the excess $\mathrm{LAH}$ decomposed with aqueous saturated $\mathrm{Na}_{2} \mathrm{SO}_{4}$. The supernatant ether layer was decanted, the solid residue extracted with ether and the combined organic extract concentrated to give 
pure 6. yield: $5.95 \mathrm{~g}\left(87 \%\right.$ ); mp: $48{ }^{\circ} \mathrm{C}$, (lit. [15] mp: $48{ }^{\circ} \mathrm{C}$ ); UV: 280 (log e 3.28) nm; IR: 3350, 2950, 1580, $830 \mathrm{~cm}^{-1}$; PMR: $\delta 2.26\left(\mathrm{~s}, \mathrm{D}_{2} \mathrm{O}\right.$ exchangeable, $\left.1 \mathrm{H}\right), 3.8(\mathrm{~s}, 6 \mathrm{H}), 4.63(\mathrm{~s}, 2 \mathrm{H}), 6.3-6.7(\mathrm{~m}$, $3 \mathrm{H})$.

\section{3,5-Dimethoxybenzyl chloride (7)}

To a cooled $\left(0{ }^{\circ} \mathrm{C}\right)$ and stirred solution of $6(5.88 \mathrm{~g}, 0.035 \mathrm{~mol})$ and pyridine $(0.4 \mathrm{~mL})$ in ether $(100$ $\mathrm{mL})$ was added $\mathrm{SOCl}_{2}(8.0 \mathrm{~g})$ in ether $(50 \mathrm{~mL})$ in portions. The mixture was stirred for $2.5 \mathrm{~h}$ at room temperature. It was extracted with ice cold water, the ether layer separated and evaporated in vacuo and the residue recrystallized from petroleum ether to get 7 as fine shinning needles. yield: $4.95 \mathrm{~g}$ (76\%); mp: $66{ }^{\circ} \mathrm{C}$; IR: 3050, 2950, 1580, $820 \mathrm{~cm}^{-1}$; PMR: $\delta 3.83$ (s, 6H), 4.5 (s, 2H), 6.3-6.7 (m, 3H).

\section{5-(2'-Heptadecynyl)-rescorcinol dimethylether $(\mathbf{8})$}

To a cooled $\left(-78{ }^{\circ} \mathrm{C}\right)$ and stirred mixture of $3(5.5 \mathrm{~g}, 0.025 \mathrm{~mol})$ in THF $(100 \mathrm{~mL})$ was added $n$ BuLi (15 mL, $0.024 \mathrm{~mol}, 1.6 \mathrm{M}$ in hexane). After stirring for $0.5 \mathrm{~h}, \mathrm{CuI}(1.9 \mathrm{~g}, 0.01 \mathrm{~mol})$ was added followed by the chloride $7(3.72 \mathrm{~g}, 0.02 \mathrm{~mol})$ in THF $(25 \mathrm{~mL})$. The the mixture was slowly brought to room temperature and stirred for $5 \mathrm{~h}$. It was poured in cold water, the organic layer separated and the aqueous layer extracted with ether. The combined organic extract was washed with water and brine and dried. Removal of solvent followed by distillation gave pure 8. yield: $3.05 \mathrm{~g}$ (41\%); bp: 155-160 ${ }^{0} \mathrm{C} / 0.2 \mathrm{~mm}$; IR: 2995, 1600, 1210, 825, $680 \mathrm{~cm}^{-1}$; PMR: $\delta 0.9$ (dist. t, 3H), 1.3 (br. s, 24H), 2.2 (t, $J=6$ $\mathrm{Hz}, 2 \mathrm{H}), 2.83(\mathrm{~s}, 2 \mathrm{H}), 3.8(\mathrm{~s}, 6 \mathrm{H}), 6.35(\mathrm{~m}, 3 \mathrm{H})$. Anal Calcd. for $\mathrm{C}_{25} \mathrm{H}_{40} \mathrm{O}_{2}: \% \mathrm{C} 80.59, \% \mathrm{H} 10.82$; Found: \%C 80.45, \%H 10.60.

\section{5-(2'(Z)-Heptadecenyl)-resorcinol dimethylether (9)}

A mixture of $8(1.86 \mathrm{~g}, 5.0 \mathrm{mmol})$ and triethylamine (TEA) $(0.2 \mathrm{~mL})$ and $5 \% \mathrm{Pd}-\mathrm{CaCO}_{3}(50 \mathrm{mg})$ in THF $(20 \mathrm{~mL})$ was shaken under a slight positive pressure of $\mathrm{H}_{2}$. After the required uptake of $\mathrm{H}_{2}$, the reaction mixture was diluted with ether $(20 \mathrm{~mL})$ and passed through a short pad of silica gel. The eluent was washed with dil. $2 \mathrm{~N} \mathrm{HCl}$, water and brine and dried. Removal of solvent afforded pure 9. yield: $1.54 \mathrm{~g}$ (83\%); bp: 155-160 ${ }^{0} \mathrm{C} / 0.1 \mathrm{~mm}$; IR: 3010, 2995, 1600, 1210, 835, $690 \mathrm{~cm}^{-1}$; PMR: $\delta 0.9$ (dist. t, 3H), 1.32 (br. s, 24H), 1.9-2.1 (m, 2H), 2.56 (d, $J=6 \mathrm{~Hz}, 2 \mathrm{H}), 3.8(\mathrm{~s}, 6 \mathrm{H}), 5.4-5.5(\mathrm{~m}, 2 \mathrm{H})$, 6.33 (s, 3H); MS (m/z): $374\left(\mathrm{M}^{+}\right)$, 191, 183, 168, 151, 137, 136, 121, 57, 43. Anal Calcd. for $\mathrm{C}_{25} \mathrm{H}_{42} \mathrm{O}_{2}$ : \% $80.16, \% \mathrm{H} 11.30$; Found: \%C 79.95, \%H 11.15 .

\section{5-(2'(Z)-Heptadecenyl)-resorcinol (10)}

To a cooled $\left(-78{ }^{\circ} \mathrm{C}\right)$ and stirred solution of $9(0.374 \mathrm{~g}, 1.0 \mathrm{mmol})$ in $\mathrm{CH}_{2} \mathrm{Cl}_{2}(10 \mathrm{~mL})$ was injected $\mathrm{BBr}_{3}(3.0 \mathrm{mmol})$. After stirring for $6 \mathrm{~h}$ at the same temperature and $12 \mathrm{~h}$ at room temperature, the 
reaction was quenched with aqueous saturated $\mathrm{NH}_{4} \mathrm{Cl}$ solution, the organic layer separated washed with water and brine and dried. Removal of solvent followed by preparative TLC of the crude product (5\% $\mathrm{MeOH} / \mathrm{CHCl}_{3}$ as the developing solvent, silica gel) furnished pure 10 [4]. yield: $0.245 \mathrm{~g}$ (71\%); IR: 3440, 3010, 3000, 1600, 840, $680 \mathrm{~cm}^{-1}$; PMR: $\delta 0.88$ (dist. t, 3H), 1.3 (br. s, 24H), 1.9-2.1 (m, $2 \mathrm{H}), 2.54(\mathrm{~d}, J=6 \mathrm{~Hz}, 2 \mathrm{H}), 5.3-5.5$ (m, 2H), 6.24 (br. s, $\mathrm{D}_{2} \mathrm{O}$ excnahgeable, 2H), 6.4-6.55 (m, 3H).

\section{1-Tetrahydropyranyloxy-10-bromodecane (13)}

A mixture of the diol $11(8.7 \mathrm{~g}, 0.05 \mathrm{~mol})$ and $48 \% \mathrm{HBr}(20 \mathrm{~mL})$ in heptane $(50 \mathrm{~mL})$ was refluxed for $4 \mathrm{~h}$. The organic layer was separated, a fresh lot of heptane $(50 \mathrm{~mL})$ added and refluxing continued for another $4 \mathrm{~h}$. The process was repeated four times, the organic extracts were combined and washed successively with aqueous $5 \% \mathrm{NaHCO}_{3}$, water and brine and dried. Solvent removal followed by column chromatography of the residue (silica gel, 0-15\% EtOAc/hexane) afforded 12. yield: $8.3 \mathrm{~g}$ (70\%); bp: $125-127{ }^{\circ} \mathrm{C} / 3 \mathrm{~mm}$, (lit. [16] bp: 166-169 ${ }^{\circ} \mathrm{C} / 10 \mathrm{~mm}$ ); IR: 3340, 1450, 1250, $1050 \mathrm{~cm}^{-1}$; PMR: $\delta 1.33$ (br. s, 16H), 1.65 (s, $\mathrm{D}_{2} \mathrm{O}$ exchangeable, $\left.1 \mathrm{H}\right), 3.45(\mathrm{t}, J=6 \mathrm{~Hz}, 2 \mathrm{H}), 3.62(\mathrm{t}, J=6 \mathrm{~Hz}$, 2H).

A solution of 12 (7.1 g, $0.03 \mathrm{~mol})$ and 3,4-dihydropyran (DHP) (2.9 g, $0.04 \mathrm{~mol})$ and pyridinium para-toluenesulphonate (PPTS) $(0.5 \mathrm{~g})$ in $\mathrm{CH}_{2} \mathrm{Cl}_{2}(50 \mathrm{~mL})$ was stirred at room temperature for $4 \mathrm{~h}$. The reaction mixture was washed with aqueous $10 \% \mathrm{NaHCO}_{3}$, water and brine. After drying and solvent removal, the residue was column chromatographed (silica gel, $0-10 \%$ ether/hexane) to give pure 13. yield: $7.8 \mathrm{~g}$ (81\%); IR: 2920, 1460, 910, $870 \mathrm{~cm}^{-1}$; PMR: $\delta 1.33$ (br. s, 16H), 1.6-1.8 (m, 6H), 3.28-3.65 (m, 6H), 4.6 (br. s, $1 \mathrm{H})$.

\section{Hexadec-11-yn-1-ol (15)}

To a stirred suspension of $\mathrm{NaNH}_{2}$ [prepared from $\mathrm{Na}(3.00 \mathrm{~g}, 0.013 \mathrm{~mol})$ ] in $\mathrm{NH}_{3}(100 \mathrm{~mL})$ was added 1-hexyne $(14.7 \mathrm{~mL}, 0.13 \mathrm{~mol})$ in THF $(50 \mathrm{~mL})$. The mixture was stirred for $2 \mathrm{~h}$, most of the $\mathrm{NH}_{3}$ was evaporated and the content resuspended in THF $(70 \mathrm{~mL})$. To this was added 13 (32.0 g, 0.1 $\mathrm{mol})$ in THF $(30 \mathrm{~mL})$ at $-78{ }^{0} \mathrm{C}$. The mixture was stirred for $5 \mathrm{~h}$ at the same temperature, treated with aqueous saturated $\mathrm{NH}_{4} \mathrm{Cl}$ and the organic layer separated. The aqueous portion was extracted with ether, the combined organic extract washed with water and brine and dried. Removal of solvent gave 14 which was taken in $\mathrm{MeOH}(100 \mathrm{~mL})$ and refluxed for $3 \mathrm{~h}$ in the presence of para-toluenesulphonic acid (PTS) (0.5 g). Most of the solvent was removed in vacuo, water added to it and the mixture extracted with ether. The ether layer was washed with aqueous $5 \% \mathrm{NaHCO}_{3}$, water and brine and dried. Removal of solvent followed by distillation gave 15. yield: $14.6 \mathrm{~g}(61 \%)$; bp: $138{ }^{\circ} \mathrm{C} / 2 \mathrm{~mm}$; IR: 3360, 1480, $1070 \mathrm{~cm}^{-1}$; PMR: $\delta 0.88$ (dist. t, 3H), 1.32 (br. s, 20H), 1.53 (s, $\mathrm{D}_{2} \mathrm{O}$ exchangeable, $1 \mathrm{H}$ ), 2.1-2.3 (m, 4H), $3.66(\mathrm{t}, J=6 \mathrm{~Hz}, 2 \mathrm{H})$. 


\section{(11Z)-Hexadec-11-en-1-ol (16)}

To a stirred solution of $\mathrm{Ni}(\mathrm{OAc})_{2}(1.24 \mathrm{~g}, 5.0 \mathrm{mmol})$ in EtOH $(50 \mathrm{~mL})$ was added $\mathrm{NaBH}_{4}(0.285 \mathrm{~g}$, $7.5 \mathrm{mmol}$ ). Within $5 \mathrm{~min}$, a black suspension of P-2 $\mathrm{Ni}$ formed and the evolution of $\mathrm{H}_{2}$ ceased. Ethylenediamine (EDA) (0.9 g) was added to it followed by 15 (11.9 g, $0.05 \mathrm{~mol})$ and the mixture shaken in an atmosphere of $\mathrm{H}_{2}$. After the required uptake of $\mathrm{H}_{2}$, the mixture was diluted with ether and the supernatant passed through a pad of silica gel. The eluent was concentrated and the residue distilled to get pure 16. yield: $9.71 \mathrm{~g}(81 \%)$; bp: $145{ }^{\circ} \mathrm{C} / 1.5 \mathrm{~mm}$; IR: 3390, 3010, $1470,1065 \mathrm{~cm}^{-1}$; PMR: $\delta 0.9$ (dist. t, 3H), 1.29 (br. s, 20H), 1.8 (s, $\mathrm{D}_{2} \mathrm{O}$ exchangeable, $\left.1 \mathrm{H}\right), 2.0-2.3(\mathrm{~m}, 4 \mathrm{H}), 3.68(\mathrm{t}, J=$ $6 \mathrm{~Hz}, 2 \mathrm{H}), 5.4-5.5(\mathrm{~m}, 2 \mathrm{H})$.

\section{(11Z)-1-Bromohexadec-11-ene (17)}

To a cooled $\left(0{ }^{0} \mathrm{C}\right)$ and stirred solution of $\mathrm{Ph}_{3} \mathrm{P}(9.5 \mathrm{~g}, 0.04 \mathrm{~mol})$ in $\mathrm{CH}_{2} \mathrm{Cl}_{2}(50 \mathrm{~mL})$ was added

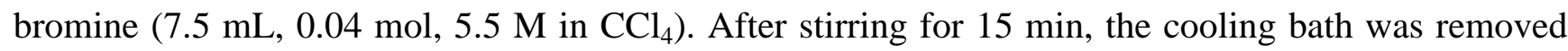
and a mixture of $16(7.2 \mathrm{~g}, 0.03 \mathrm{~mol})$ and pyridine $(3 \mathrm{~mL})$ in $\mathrm{CH}_{2} \mathrm{Cl}_{2}(20 \mathrm{~mL})$ introduced into the mixture. After stirring for $2 \mathrm{~h}$, the mixture was concentrated, the residue extracted with hexane and the supernatant decanted. The hexane layer was passed through a pad $(50 \mathrm{~mm})$ of neutral alumina and concentrated in vacuo to afford pure 17. yield: $6.3 \mathrm{~g}(69 \%)$; bp: $128{ }^{\circ} \mathrm{C} / 0.5 \mathrm{~mm}$; IR: 2995, 1470, 1250 $\mathrm{cm}^{-1}$; PMR: $\delta 0.9$ (dist. t, 3H), 1.3 (br. s, 20H), 1.7-2.3 (m, 4H), 3.48 (t, $J=6 \mathrm{~Hz}, 2 \mathrm{H}$ ), 5.3-5.5 (m, $2 \mathrm{H})$.

\section{1-(3',5'-Dimethoxyphenyl)-heptadec-12-en-1-ol (18)}

To a cooled $\left(0{ }^{0} \mathrm{C}\right)$ and stirred solution of the Grignard reagent [prepared from 17 (6.0 g, $\left.0.02 \mathrm{~mol}\right)$ and $\mathrm{Mg}(0.528 \mathrm{~g}, 0.022 \mathrm{~mol})$ in THF $(60 \mathrm{~mL})$ ] was added 3,4-dimethoxybenzaldehyde $(3.32 \mathrm{~g}, 0.02$ $\mathrm{mol})$ in THF $(20 \mathrm{~mL})$. After stirring for $4 \mathrm{~h}$, the reaction was quenched with aqueous saturated $\mathrm{NH}_{4} \mathrm{Cl}$ solution, the organic portion separated and the aqueous layer extracted with ether. The combined organic extract was washed with water and brine and dried. Removal of solvent followed by column chromatography of the residue (silica gel, 0-15\% EtOAc/hexane) gave 18. yield: 4.1g (52\%); bp: 145$147{ }^{0} \mathrm{C} / 0.05 \mathrm{~mm}$; IR: 3420, 3010, 1610, 1170, $1075 \mathrm{~cm}^{-1}$; PMR: $\delta 0.9$ (dist. t, 3H), 1.29 (br. s, 22H), $1.5\left(\mathrm{~s}, \mathrm{D}_{2} \mathrm{O}\right.$ exchangeable, $\left.1 \mathrm{H}\right), 1.9-2.3(\mathrm{~m}, 4 \mathrm{H}), 3.76(\mathrm{~s}, 6 \mathrm{H}), 4.12(\mathrm{t}, J=6 \mathrm{~Hz}, 1 \mathrm{H}), 5.3-5.5(\mathrm{~m}, 2 \mathrm{H})$, 6.33 (m, 3H). Anal. Calcd. for $\mathrm{C}_{25} \mathrm{H}_{42} \mathrm{O}_{3}: \% \mathrm{C} 76.87, \% \mathrm{H} \mathrm{10.84;} \mathrm{Found:} \mathrm{\% C} \mathrm{77.08,} \mathrm{\% H} \mathrm{11.04.}$

\section{5-(12'(Z)-Heptadecenyl)-resorcinol dimethyl ether (19)}

To a cooled $\left(0{ }^{\circ} \mathrm{C}\right)$ and stirred solution of $18(3.9 \mathrm{~g}, 0.01 \mathrm{~mol})$ and TEA $(2.1 \mathrm{~mL}, 0.012 \mathrm{~mol})$ in $\mathrm{CH}_{2} \mathrm{Cl}_{2}(30 \mathrm{~mL})$ was added mesyl chloride $(1.1 \mathrm{~mL}, 0.012 \mathrm{~mol})$. The mixture was stirred at the same 
temperature for $3 \mathrm{~h}$, poured in ice-water, the organic layer separated and the aqueous portion extracted with $\mathrm{CHCl}_{3}$. The combined organic extract was washed with water and brine, dried and concentrated in vacuo to get a residue which was used directly for the next step.

To a stirred suspension of LAH $(0.76 \mathrm{~g}, 0.02 \mathrm{~mol})$ in ether $(50 \mathrm{~mL})$ was dropwise added the above mesylate in ether $(20 \mathrm{~mL})$. The mixture was refluxed for $8 \mathrm{~h}$, brought to room temperature and treated with aqueous saturated $\mathrm{Na}_{2} \mathrm{SO}_{4}$. The resultant mixture was filtered, the eluent concentrated and the residue purified by distillation to furnish pure 19. yield: $1.82 \mathrm{~g}(90 \%)$; bp: $152{ }^{\circ} \mathrm{C} / 0.02 \mathrm{~mm}$; IR: 3000 , 2940, 1610, 1470, 1220, $1150 \mathrm{~cm}^{-1}$; PMR: $\delta 0.9$ (dist. t, 3H), 1.27 (br. s, 22H), 1.8-2.2 (m, 4H), 2.68 (t, $J=6 \mathrm{~Hz}, 2 \mathrm{H}), 3.76(\mathrm{~s}, 6 \mathrm{H}), 5.3-5.5(\mathrm{~m}, 2 \mathrm{H}), 6.33(\mathrm{~s}, 3 \mathrm{H}) ; \mathrm{MS}(\mathrm{m} / \mathrm{z}): 374\left(\mathrm{M}^{+}\right), 304,223,151,137$, 136, 57. Anal. Calcd. for $\mathrm{C}_{25} \mathrm{H}_{42} \mathrm{O}_{2}$ : \% $80.16, \% \mathrm{H} 11.30$; Found: \%C 80.35, \%H 11.12.

\section{5-(12'(Z)-Heptadecenyl)-resorcinol (20)}

As described for 10, demethylation of $19(0.374 \mathrm{~g}, 1.0 \mathrm{mmol})$ was carried out with $\mathrm{BBr}_{3}(3.0$ $\mathrm{mmol})$ in $\mathrm{CH}_{2} \mathrm{Cl}_{2}(10 \mathrm{~mL})$. The resultant product was purified by preparative TLC of (5\% $\mathrm{MeOH} / \mathrm{CHCl}_{3}$ as the developing solvent, silica gel) to furnish pure 20. yield: $0.235 \mathrm{~g}(68 \%)$; IR: 3400, 3030, 3010, 1610, 1210, $1160 \mathrm{~cm}^{-1}$; PMR: $\delta 0.9$ (dist. t, 3H), 1.30 (br. s, 22H), 1.9-2.1 (m, 4H), 2.55 $(\mathrm{t}, J=6 \mathrm{~Hz}, 2 \mathrm{H}), 5.3-5.5$ (m, 2H), 6.4-6.5 (m, 3H), 8.1 (br. s, $\mathrm{D}_{2} \mathrm{O}$ excnahgeable, $\left.2 \mathrm{H}\right)$.

\section{1-Bromo-undec-10-ene (22)}

As described for 17, bromination of $21(8.5 \mathrm{~g}, 0.05 \mathrm{~mol})$ was carried out with $\mathrm{Ph}_{3} \mathrm{P}(13.2 \mathrm{~g}, 0.05$ mol) and bromine $\left(10.0 \mathrm{~mL}, 0.05 \mathrm{~mol}, 5.5 \mathrm{M}\right.$ in $\left.\mathrm{CCl}_{4}\right)$ and pyridine $(5 \mathrm{~mL})$ in $\mathrm{CH}_{2} \mathrm{Cl}_{2}(75 \mathrm{~mL})$. Usual isolation afforded pure 22. yield: $10.0 \mathrm{~g}$ (85\%); bp: $114-115{ }^{\circ} \mathrm{C} / 5 \mathrm{~mm}$, (lit. [17] bp: $103{ }^{\circ} \mathrm{C} / 4 \mathrm{~mm}$ ); IR: 3070, 1640, 1460, 990, $910 \mathrm{~cm}^{-1}$; PMR: $\delta 1.33$ (br. s, 14H), 1.9-2.2 (m, 2H), $3.56(\mathrm{t}, J=6 \mathrm{~Hz}, 2 \mathrm{H})$, 4.8-6.3 (m, 3H).

\section{1-(3',5'-Dimethoxyphenyl)-dodec-11-en-1-ol (23)}

To a cooled $\left(0{ }^{\circ} \mathrm{C}\right)$ and stirred solution of the Grignard reagent prepared from $22(9.32 \mathrm{~g}, 0.04 \mathrm{~mol})$ and $\mathrm{Mg}$ (1.06 g, $0.04 \mathrm{~mol})$ in THF (50 mL) was dropwise added 3,5-dimethoxybenzaldehyde (6.64 g, $0.04 \mathrm{~mol})$ in THF $(30 \mathrm{~mL})$. Stirring was continued at the same temperature for $2 \mathrm{~h}$ and at room temperature for $12 \mathrm{~h}$. It was quenched with aqueous saturated $\mathrm{NH}_{4} \mathrm{Cl}$, the organic layer separated and the aqueous portion extracted with ether. The organic extract was washed with water and brine and dried. Removal of solvent followed by distillation gave pure 23. yield: 8.9 g (63\%); bp: 133-135 ${ }^{0} \mathrm{C} / 1.5 \mathrm{~mm}$; IR: 3400, 3120, 1650, 1470, 995, $915 \mathrm{~cm}^{-1}$; PMR: $\delta 1.33$ (br. s, 16H), 1.9-2.5 (m, 2H), 2.84 (br. s, $\mathrm{D}_{2} \mathrm{O}$ exchangeable, $\left.1 \mathrm{H}\right), 3.8(\mathrm{~s}, 6 \mathrm{H}), 4.16(\mathrm{t}, J=6 \mathrm{~Hz}, 1 \mathrm{H}), 4.8-6.3(\mathrm{~m}, 3 \mathrm{H}), 6.5-7.1$ (m, $3 \mathrm{H})$. Anal Calcd. for $\mathrm{C}_{20} \mathrm{H}_{32} \mathrm{O}_{3}$ : \% C 74.96, \%H 10.07; Found: \%C 74.85, \% 9.90. 


\section{1-(3',5'-Dimethoxyphenyl)-dodec-11-ene (24)}

As described for the preparation of 19, mesylation of $\mathbf{2 3}(8.0 \mathrm{~g}, 0.025 \mathrm{~mol})$ with mesyl chloride $(2.2 \mathrm{~mL}, 0.025 \mathrm{~mol})$ was carried out in the presence of triethyl amine $(4.2 \mathrm{~mL}, 0.025 \mathrm{~mol})$ in $\mathrm{CH}_{2} \mathrm{Cl}_{2}$ $(60 \mathrm{~mL})$. The resultant product was directly reduced with $\mathrm{LAH}(1.9 \mathrm{~g}, 0.05 \mathrm{~mol})$ in ether $(75 \mathrm{~mL})$. The product 24 obtained was purified by distillation. yield: $6.1 \mathrm{~g}(80 \%)$; bp: $128-130^{\circ} \mathrm{C} / 1 \mathrm{~mm}$; IR: 3120 , 1650, 1470, 1000, $915 \mathrm{~cm}^{-1}$; PMR: $\delta 1.27$ (br. s, 16H), 1.9-2.3 (m, 4H), $3.8(\mathrm{~s}, 6 \mathrm{H}), 4.8-6.3(\mathrm{~m}, 3 \mathrm{H})$, 6.5 (m, 3H). Anal Calcd. for $\mathrm{C}_{20} \mathrm{H}_{32} \mathrm{O}_{2}: \% \mathrm{C} 78.89$, \%H 10.59; Found: \%C 78.80, \% 10.45 .

\section{2-(3',5'-Dimethoxyphenyl)-dodecanal (26)}

To a stirred suspension of $\mathrm{NaBH}_{4}(2.3 \mathrm{~g}, 0.06 \mathrm{~mol})$ in 1,2-dimethoxyethane (DME) (25 mL) was injected $\mathrm{TiCl}_{4}(3.5 \mathrm{~mL}, 0.03 \mathrm{~mol})$ and the mixture stirred for $1 \mathrm{~h}$. To this was added the alkene 24 $(6.08 \mathrm{~g}, 0.02 \mathrm{~mol})$ and stirring continued for $16 \mathrm{~h}$ at room temperature. The excess hydride was carefully decomposed by addition of water and the mixture extracted with ether. The ether layer was washed with water and brine and dried. Removal of solvent followed by distillation gave pure 25 . yield: 5.0 g (77\%); bp: $144-145{ }^{\circ} \mathrm{C} / 0.5 \mathrm{~mm}$; IR: 3350, 3010, 1610, $1580 \mathrm{~cm}^{-1}$; PMR: $\delta 1.27$ (br. s, $20 \mathrm{H}), 2.37(\mathrm{t}, J=6 \mathrm{~Hz}, 2 \mathrm{H}), 3.2\left(\mathrm{~s}, \mathrm{D}_{2} \mathrm{O}\right.$ exchangeable, $\left.1 \mathrm{H}\right), 3.6(\mathrm{t}, J=6 \mathrm{~Hz}, 2 \mathrm{H}), 3.8(\mathrm{~s}, 6 \mathrm{H}), 6.5$ (s, $3 \mathrm{H})$.

To a stirred solution of 25 (4.85 g, $0.015 \mathrm{~mol})$ in $\mathrm{CH}_{2} \mathrm{Cl}_{2}(75 \mathrm{~mL})$ was added PCC (4.86 g, 0.022 $\mathrm{mol}$ ) in one lot. After completion of the reaction ( $c f$. TLC, $3 \mathrm{~h}$ ), the mixture was diluted with ether (75 $\mathrm{mL}$ ) and the supernatant passed through a 2" pad of silica gel. The eluent was concentrated in vacuo to give pure 26. yield: $3.65 \mathrm{~g}(76 \%)$; IR: $3000,2750,1750,1610 \mathrm{~cm}^{-1}$; PMR: $\delta 1.32$ (br. s, $\left.18 \mathrm{H}\right), 2.3-$ $2.7(\mathrm{~m}, 4 \mathrm{H}), 3.8(\mathrm{~s}, 6 \mathrm{H}), 6.33(\mathrm{~s}, 3 \mathrm{H}), 9.85(\mathrm{t}, J=1.5 \mathrm{~Hz}, 1 \mathrm{H})$.

\section{(5-(12’(Z)-Heptadecenyl)-resorcinol dimethylether (19)}

To a stirred solution of dimsyl ion [0.012 mol, in DMSO (30 mL)] was added $n$ pentyltriphenylphosphonium bromide $(5.0 \mathrm{~g}, 0.012 \mathrm{~mol})$ in portions. After stirring for $1 \mathrm{~h}$, the resulting red ylide was diluted with THF $(40 \mathrm{~mL})$, cooled to $-20{ }^{\circ} \mathrm{C}$ and the aldehyde $26(3.2 \mathrm{~g}, 0.01$ mol) in THF $(10 \mathrm{~mL})$ added in dropwise manner. Stirring was continued for $1 \mathrm{~h}$ at the same temperature and at room temperature for $12 \mathrm{~h}$. Water was added to the mixture, the organic layer separated and the aqueous portion extracted with ether. The organic extract was washed with water and brine, dried, concentrated and the residue purified as earlier to get pure 19. Its spectral data were identical with those of the product obtained by the other route. yield:1.8 $\mathrm{g}(48 \%)$. 


\section{References and Notes}

1. Lampe, K. F.; Fagerstrom, R. In Plant Toxicity and Dermatitis, Williams and Wilkins Co., Baltimore 1968; b. Fisher, A. A. In Contact Dermatitis, 2nd Edition, Lea and Fabiger Pub., Philadelphia 1973.

2. Dawson, C. R.; Wasserman, D. J. Am. Chem. Soc. 1948, 70, 3675; Symes, W. F.; Dawson, C. R. Nature 1953, 171, 841.

3. Majima, R. Chem. Ber. 1922, 55B, 172; b. Sukhtankar, S. V.; Dawson, C. R. J. Am. Chem. Soc. 1954, 76, 5070.

4. Bandopadhyay, C.; Gholap, A. S.; Mamdapur, V. R. J. Agric. Food. Chem.. 1985, 33, 377.

5. Cojocaru, M.; Dorby, S.; Glotter, E.; Goldman, A.; Gottlieb, H. E.; Jacoby, B.; Prusky, D. Phytochemistry 1986, 25, 1093.

6. Jenner, E. F.; Meier, K. D. Angew. Chem.. 1959, 71, 245.

7. Friary, R.; Seidl, V. J. Org. Chem.. 1986, 51, 3214.

8. Logemann, E.; Schill, G. Bert dt. Chem. Ges. 1978, 7, 2165.

9. Brown, C. A.; Ahuja, V. K. J.Chem.Soc. 1973, 553..

10. Wiley, G. A.; Hershkowitz, R. I.; Rein, B. M.; Chung, B. C. J. Am. Chem. Soc. 1964, 86, 964.

11. Kano, S.; Tanaka, Y.; Hibino, S. J. Chem. Soc. Chem. Commun. 1980, 415 and ref. cited therein.

12. Corey, E. J.; Suggs, J. W. Tetrahedron Lett.. 1975, 2647.

13. Brandmsa, L. In Preparative Acetylenic Chemistry, Elsevier Publ. Co., Amsterdam 1971.

14. Krafft, B. Ber. 1896, 29, 2236.

15. Ridley, D. D.; Ritchie, E.; Taylor, W. C. Aust. J. Chem.. 1968, 21, 2979.

16. Pattison, F. L. M.; Stothers, J. B.; Woolford, R. G. J. Am. Chem. Soc. 1956, 78, 2225.

17. Tomecko, C. G.; Adams, R. J. Am. Chem. Soc. 1927, 49, 522.

Samples Availability: Available from the authors.

(C) 1999 by the authors. Reproduction of this article, by any means, is permitted for noncommercial purposes. 